\title{
ECONOMICS OF EDUCATION IN SERBIA: BETWEEN HUMAN CAPITAL AND SIGNALING AND SCREENING THEORIES ${ }^{* \star}$
}

\begin{abstract}
This article analyzes education in Serbia from the point of view of the two principal strands of economic theory of education: human capital theory and the theory of signaling and screening. Based on the available statistical data from the Statistical Office, the rate of return to education is calculated for Serbia and its implications discussed. From another point of view, the comparative employment opportunities of graduates from public and private universities are discussed based on the signaling and screening theory. Since no university specific employment statistics exist at present in Serbia, only a hypothetical theoretical discussion is provided as a basis for future research. Finally, the prospects for development of education in Serbia are analyzed.
\end{abstract}

Key words: education economics, human capital, signaling and screening

\section{Introduction: The structure of the economics of education}

The economics of education is an exciting applied field of economic theory with versatile and surprising theoretical tools, and great practical significance that cannot be overemphasized. Its inception in its modern form is attributed to Theodore Schultz's address to the American Economic Association in December 1960, in which the principal theoretical paradigm, that education can be regarded as an investment in human capital, analogous to investments in physical capital, was reintroduced.

The most famous historical precedent of this idea is Adam Smith's classic statement that:

'a man educated at the expense of much labor and time to any of those employments which require extraordinary dexterity and skill, may be compared to one of those expensive machines. The work which he learns to perform, it 
must be expected, over and above the usual wages of common labor, will replace to him the whole expense of his education.'

This still remains the main trait of education economics, namely that education raises productivity, and by increased productivity compensates and earns above the investment of money and effort. In the next section we will take up this idea and calculate the internal rate of return to investment in education in Serbia and discuss the implications.

While human capital theory certainly remains pivotal for the economics of education, it is not the only theoretical paradigm. Very exciting and to a certain degree surprising body of theory has come from the microeconomic theory of asymmetric information, which is one of the cases of market failure. When employer and employee have asymmetric information concerning the capabilities and efforts of the employees, employer has to rely on some signals to distinguish among different kinds of employees. Since education is more difficult to obtain for less talented workers the level of education can signal the intrinsic abilities of employees. In the simplified model, productivity is not raised at all, the only effect is signaling. By that way, in this extreme case of signaling and screening models, the link between education and increased productivity, characteristic of human capital theory, is completely severed.

There are many related subjects of practical relevance, such as the role of investments in human capital in the emergence of South and East Asian economies; the widening gap in the distribution of incomes in the developed world in favor of highly educated workers, whether as a consequence of emergence of South and East Asian economies or the bias in technological change itself.

The question of externalities in education is another prominent topic, as externalities are in general, but the field of education is especially important in this respect. Externalities in education imply differences between the private returns to education and social returns, stressing the importance of policies to enhance education, as its importance goes above what each individual feels.

Another branch of research relates to understanding of education process itself, that is to say, how education transforms less productive into more productive individuals, or the topic of educational production function. The famous classical example is studies into influence that class size has on pupils' performance.

Lastly, an important topic has become the financing of education, the study of variety of models for funding education, which is very costly and takes significant percentage of budgets of modern states. The high costs have aroused

Assistant Professor Dejan Popov, PhD, Business School of Megatrend University, Belgrade, e-mail:dpopov@megatrend.edu.rs

** Paper presented at the $10^{\text {th }}$ N.E.W.S. Conference - Global University Network, held by Megatrend University from $10^{\text {th }}$ to $14^{\text {th }}$ September 2013 in Belgrade.

$1 \quad$ Adam Smith: The Wealth of Nations, Alfred A. Knopf., New York [1776] 1991. 
increased interest in the appropriate mechanism for financing education, among them for voucher systems.

Due to the intensive research, education economics is now a mature field of economics, with first bibliographies appearing as early as in $1966^{2}$ and many encyclopedic treatments being already available ${ }^{3,4}$, and the intensive research still goes on.

\section{Estimating rates of return to education in Serbia}

\subsection{Human capital and the rate of return to education}

As noted in the introduction, the notion of human capital means that education can be regarded as an investment that is analogous to investments in physical capital. Consequently, economically rational individuals evaluate the investment in their own education in a manner similar to that of the firms when they decide to invest in new machinery.

What makes both decisions complex is the fact that the investment in each case entails current costs, and yields future benefits; so that there is a need for a sound methodology to consistently evaluate different patterns of cash flows over an extended period of time. In the case of education the period of interest is actually the whole life span.

Many methods could be used for the purpose of selecting among alternative cash flows. Some of them are: present worth, future worth, annual worth, rate of return, payback period etc. They all entail the idea that in order to compare cash flows from different periods of time, they must be transformed into cash flows that refer to the same point of time, by means of discounting factors, so as to be comparable.

The first step in all these methods, and we are here primarily interested in the internal rate of return, is to correctly specify the schedule of cash flows in time. There is certain flexibility, depending on the aim of the research and the point of view, but we will adopt the time frame that is used in some international studies, to be more easily comparable.

For example, we will take five years as duration of high education, although it is four in Serbia for most majors. This way, we actually assume bachelor and master degree, instead of only bachelor. It means that the time period for higher

\footnotetext{
2 Blaug Mark: Economics of Education: A Selected Annotated Bibliography, Pergamon Press, Oxford 1978.

3 Johnes Geraint Jill Johnes (eds.): International handbook on the economics of education, Edward Elgar, Cheltenham UK 2004.

4 Hanushek A. Eric, Welch Finis (eds.): Handbook of the Economics of Education, North Holland, Amsterdam 2006.
} 
education would be from the age of 18 to the age of 23 . Also, we take the working period to be from the age of 23 to the age of 65 . This complies well with the retirement practices in Serbia, except that it is possible to retire after 40 working years, even before the age of 65 . These flexibilities are acceptable because the estimate of the rate of return can at best be rough approximate.

This framework for the problem of calculating the rate of return to education is illustrated by the Figures 1 and 2. The Figure 1 shows simplified view of the problem. Earnings are designated on the positive $y$ axis, and costs on the negative one, while time is measured on $x$ axis. Simplification is in that costs and earnings are taken to be constant over the whole period. That is to say, each year of study costs the same, whether on the first or the last year, and earnings also don't increase over time.

From years 18 to 23 some people undertake high education, and their costs over these five years are not only direct, like tuition fees etc., but also an opportunity cost of forgone salaries. Benefits, on the other hand consist of higher earnings after graduation. Of course, there is also a utility cost of effort invested in education from cost side, and a utility benefit of working in generally better conditions that prevail on working places that require higher education. These details are left over in this kind of rough estimate analysis.

The Figure 2 shows more realistic and general, though it is still stylized picture of the problem. Generality is in that salaries are allowed to rise with time, and education costs could also rise on the higher years of study.

Figure 1: Simplified stream of constant cash flows ${ }^{5}$

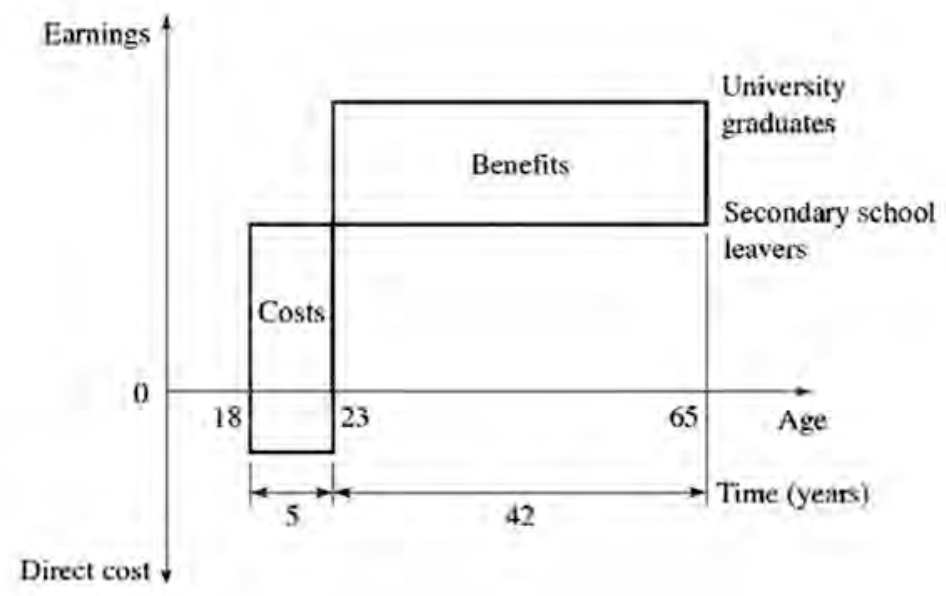

5 Johnes Geraint Jill Johnes (eds.): International handbook on the economics of education, Edward Elgar, Cheltenham UK 2004, 7. 
Figure 2: General stylized pattern of cash flows ${ }^{6}$

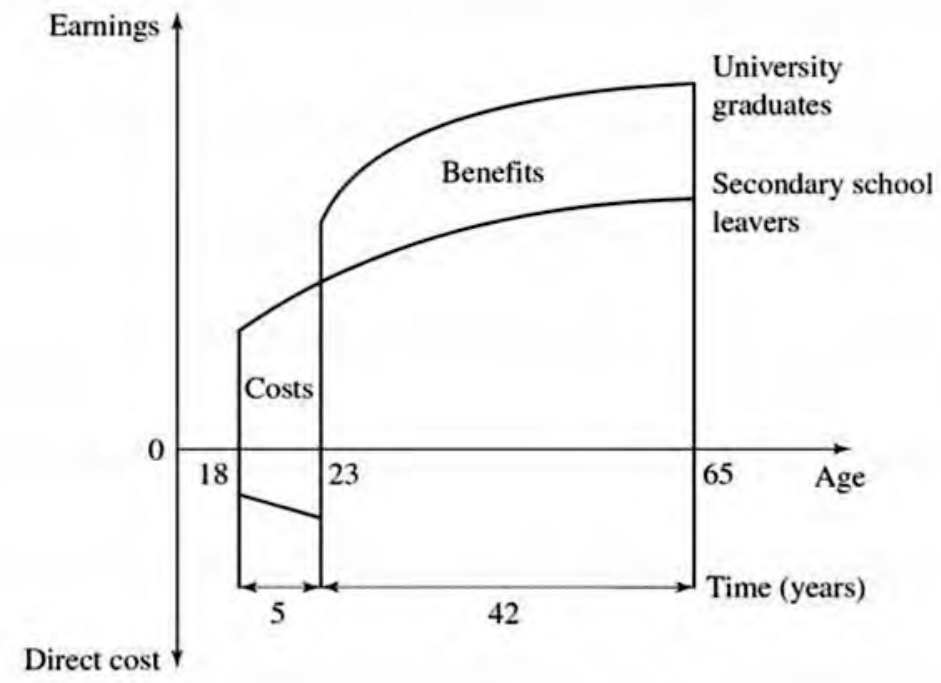

Having specified the pattern of cash flows, we now turn to the statistical data that provide the numerical values to be fitted in the above schedule. We need two kinds of data. The first one is the cost of each year of study. For this data we take the cost to be 1500 EUR, the cost of studying at the private universities, in dinar value according to the exchange rate of 114 dinars for 1 EUR.

The other part of the data is the average salaries and wages by level of educational attainment. This data is available from Statistical Office of the Republic of Serbia and is presented in the next section.

\subsection{The Data}

Estimation of the rate of return to education crucially depends on the availability of data on average salaries and wages specific by level of educational attainment. Statistical Office of the Republic of Serbia is publishing such data under the section Employment and Earnings, Statistical Releases ZP12.

Data are derived from the regular semi-annual statistical survey on employees and their salaries and wages (RAD-1), which is carried out twice a year (as of 31 March and 30 September). That means that data in this article are the newest available, that of 31 March.

The survey covers employees in legal entities (enterprises, institutions, cooperatives and organizations). Employees that are not covered by this survey are those engaged in some small-size enterprises and in unincorporated enterprises (entrepreneurs), as well as employees in Ministry of Defense and in Ministry of Interior.

Ibid., 4. 
What is important to have in mind is that the salaries and wages are defined pursuant to the Law on Labor ("Official Journal of the Republic of Serbia", no 24/2005 and 61/2005). This is to say that gross (including contributions for social security), and not net salaries are presented. That is why to an observer familiar with economic conditions in Serbia numbers might look higher than expected.

Figure 2 presents the data from the statistical release in table, while Figure 3 presents the data in a convenient graphical form. We will use only the total numbers, as there is no need for the purpose of this article to distinguish between sexes.

Table 1: Average salaries and wages by level of educational attainment ${ }^{7}$

\begin{tabular}{|c|c|c|c|c|c|c|c|c|}
\hline \multicolumn{9}{|c|}{ Average salaries and wages by level of educational attainment and sex, March 2013} \\
\hline & & & & & & & & RSD \\
\hline & \multicolumn{8}{|c|}{ Republic of Serbia } \\
\hline & Total & \multicolumn{3}{|c|}{ Serbia - North } & \multicolumn{4}{|c|}{ Serbia - South } \\
\hline & & Total & $\begin{array}{c}\text { City of } \\
\text { Belgrade }\end{array}$ & $\begin{array}{l}\text { Region of } \\
\text { Vojvodina }\end{array}$ & Total & $\begin{array}{c}\text { Region of } \\
\text { Sumadija } \\
\text { and } \\
\text { Western } \\
\text { Serbia } \\
\end{array}$ & $\begin{array}{c}\text { Region of } \\
\text { Southern } \\
\text { and } \\
\text { Eastern } \\
\text { Serbia } \\
\end{array}$ & $\begin{array}{l}\text { Region } \\
\text { of } \\
\text { Kosovo } \\
\text { and } \\
\text { Metohia }\end{array}$ \\
\hline Total & 62102 & 68777 & 75900 & 59839 & 52667 & 52296 & 53114 & $\ldots$ \\
\hline $\begin{array}{l}\text { University } \\
\text { educational } \\
\text { attainment }\end{array}$ & 97228 & 108293 & 117850 & 93640 & 78809 & 78749 & 78880 & $\cdots$ \\
\hline $\begin{array}{l}\text { Vocational } \\
\text { higher } \\
\text { educational } \\
\text { attainment }\end{array}$ & 65279 & 70645 & 74844 & 64828 & 57784 & 57921 & 57623 & ... \\
\hline $\begin{array}{l}\text { Secondary } \\
\text { educational } \\
\text { attainment }\end{array}$ & 53611 & 57352 & 61455 & 52220 & 47684 & 47820 & 47539 & ... \\
\hline $\begin{array}{l}\text { Lower } \\
\text { educational } \\
\text { attainment }\end{array}$ & 36949 & 38592 & 39705 & 37384 & 34552 & 36909 & 31794 & $\cdots$ \\
\hline Highly qualified & 68240 & 71454 & 73012 & 67496 & 63294 & 56054 & 75061 & $\ldots$ \\
\hline Qualified & 46056 & 49335 & 52925 & 45640 & 42433 & 41699 & 43411 & $\ldots$ \\
\hline Semi-qualified & 37711 & 40230 & 41929 & 38563 & 35513 & 35498 & 35535 & $\ldots$ \\
\hline Non-qualified & 34317 & 36805 & 36090 & 37213 & 31784 & 31597 & 32021 & $\ldots$ \\
\hline
\end{tabular}

Source: Statistical Office of the Republic of Serbia: "Employees in legal entities in the Republic of Serbia, by salaries and wages size and level of educational attainment, March 2013 (ZP12)", 9, http://webrzs.stat.gov.rs/WebSite/repository/documents/00/01/07/99/ zp12072013e.pdf (06.09.2013). 
For us the data on average salaries and wages for two levels of educational attainment are important, those for university educational attainment, 97.228 dinar, and secondary educational attainment, 53.611 dinar. Those will be utilized in Section 2.4 to calculate the ROR.

Figure 3: Average salaries and wages by employees' sex and level of educational attainment, March 2013 Republic of Serbia ${ }^{8}$

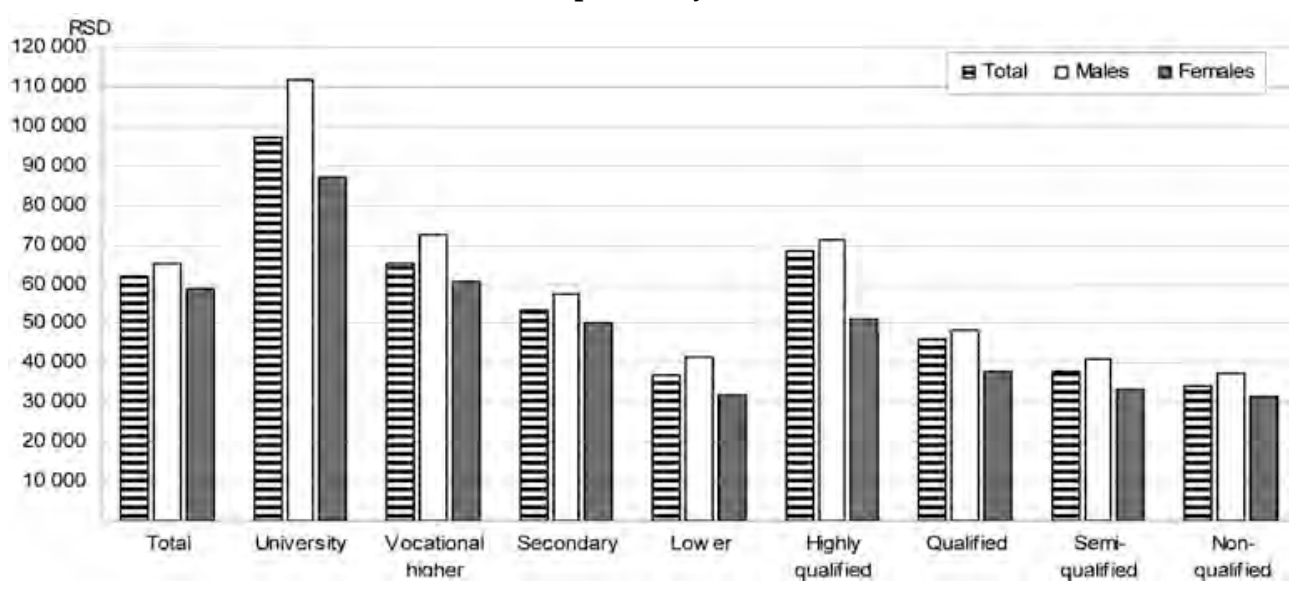

\subsection{Methodology}

What makes investment decisions complex both in physical and human capital case is the fact that the investment in each case entails current costs, and yields future benefits; so that there is a need for a sound methodology to consistently evaluate different patterns of cash flows over extended period of time. In the case of education the period of interest is actually the whole life span.

When there are such cash flows over an extended period of time, then in order to make meaningful economic decisions and comparisons, it is not sufficient to just add benefits, add costs and then subtract overall costs from the benefits, because, for example, it is not economically the same to have a stream of $1000 \$$ costs today and $2000 \$$ benefit next year, or the same costs and benefits but $2000 \$$ arriving only after five years. Obviously, preferable is the first pattern.

The reason is the time value of money, the fact that $1 \$$ is worth more today than next year, although nominally is the same, but dollar today can earn interest over a year, and is therefore equivalent to more than one dollar in a one year time.

Many methods could be used for the purpose of selecting among alternative cash flows. Some of them are: present worth, future worth, annual worth, rate of return, payback period etc. They all entail the idea that in order to compare

Ibid.

Vol. 11, No 1, 2014: 241-258 
cash flows from different times they must be, by means of discounting factors, transformed into cash flows in the same point in time so as to be comparable.

Among them, the method of internal rate of return is the one that determines the implicit rate of return, the rate of return which, when used as a discounting factor, equalizes costs and benefits, making the present value of the stream of cash flows equal to zero. In other words, internal rate of return is the discounting rate that makes the net value of the investment zero.

With the assumption that high education lasts five years and working period forty two, the rate of return $r$ is the solution of the following equation:

$$
\sum_{t=1}^{42} \frac{\left(W_{u}-W_{s}\right)_{t}}{(1+r)^{t}}=\sum_{t=1}^{5}\left(W_{s}+C_{u}\right)_{t}(1+r)^{t}
$$

Where $\mathrm{W}_{\mathrm{u}}$ is the earnings of university graduate (W standing for wage and subscript $u$ for university graduate), $\mathrm{W}_{\mathrm{s}}$ the earnings of a secondary school graduate (subscript $s$ for secondary), and $\mathrm{C}_{\mathrm{u}}$ designates the direct costs of university education (tuition, fees, books).

This formula entails that present value of the investment is calculated for the time point of graduation and beginning of the working period. Obviously, other point of time, like beginning of the study period could equivalently be chosen.

The internal rate of return implies that financing of education by loans with interest rate less than ROR would imply positive present value and would be therefore economically feasible.

\subsection{Calculation of the internal rate of return}

Now we can actually calculate the ROR to education. With 1500 EUR annual tuition, under the exchange rate of 114 RSD per 1 EUR, the annual tuition in dinars is $-171000 \mathrm{RSD}$, minus sign denoting costs.

To have full costs we must add the forgone salaries for the same one year period. Since in the period before graduation the salary would be that of the workers with secondary educational attainment, the foregone salaries are 53611 times twelve months: $53611 \times 12=814332$. It is important not to forget to multiply with 12 months, as calculation is on an annual basis.

On the side of benefits, our data show that the average salary for the university educational attainment is 97.228 dinar, and for the secondary educational attainment is 53.611 dinar. Then the net benefit of education is measured by their difference: $97.228-53.611=43617$, which again must be multiplied by 12 to get the annual value: 43617 x $12=523404$.

These data can now be filled into Excel sheet: for the first five years, -814332 , and for the rest 42 years, 523404. ROR can be calculated by Excel's convenient built-in function IRR(). Its syntax is: 
IRR(first_cell, last_cell),

Or, having in mind that theoretically it is possible that ROR is not unique, a guess value can be inserted into IRR() function to single out the expected ROR value from the set of possible ones.

IRR(first_cell:last_cell, guess)

In the cash flow streams of practical significance this rarely happens.

Table 2: shows the data and the calculated rate of return.

Table 2: Calculation of the rate of return to education in Serbia

\begin{tabular}{|c|c|c|}
\hline year & cash flow & \\
\hline-5 & -814332 & IRR \\
\hline-4 & -814332 & $10 \%$ \\
\hline-3 & -814332 & \\
\hline-2 & -814332 & \\
\hline-1 & -814332 & \\
\hline 1 & 523404 & \\
\hline 2 & 523404 & \\
\hline 3 & 523404 & \\
\hline 4 & 523404 & \\
\hline 5 & 523404 & \\
\hline 6 & 523404 & \\
\hline 7 & 523404 & \\
\hline 8 & 523404 & \\
\hline ........ & $\ldots \ldots \ldots$ & \\
\hline 35 & 523404 & \\
\hline 36 & 523404 & \\
\hline 37 & 523404 & \\
\hline 38 & 523404 & \\
\hline 39 & 523404 & \\
\hline 40 & 523404 & \\
\hline 41 & 523404 & \\
\hline 42 & 523404 & \\
\hline
\end{tabular}

The result for the internal rate of return obtained is $10 \%$. This number complies well with the fact that average returns to schooling are lowest for the non- 
OECD European, Middle East and North African group of countries, Serbia belonging to non-OECD European countries. For the world as a whole, average is $10.8 \%$, (since we have not included subsidization of education, our estimate should be compared with data for full or 'social' returns).

Although the calculated rate of return to education is not among the highest in the world, it testifies to the fact that it is still very well worth for students to invest in education in Serbia, as opposed to leaving education after secondary school. This can explain the fact that almost all available places in public universities are occupied, and that private universities also have great number of students.

And it should be kept in mind that the rate that we obtained is the minimal estimate. As pointed before, if the fact that most of the students in public universities don't pay tuition fees is taken into account, together with the fact that the first year is free of charge on some private universities, then on average the rate of return would be even higher. Also, when other benefits of working on working places that require higher education are taken into account, the meaningful rate of return would be considerably higher. Therefore, from the individualistic economic perspective, education should be in high demand.

\section{Comparative employment opportunities of graduates from public and private universities from the signaling and screening perspective}

\subsection{Assymetric information and signaling and screening}

Asymmetric information is one of the notable cases of market failure - situations when market does not result in an efficient Pareto-optimal state. Baseline models that guarantee Pareto-optimality all assume that both buyers and sellers are perfectly informed about the quality of the goods being sold in the market. However, this assumption is violated in practice on many markets, and if it is costly to verify the quality of goods, this can make problems to the efficient operation of markets.

This is essentially because, since it is impossible to distinguish between products of different quality, only one price would prevail, by means of which the sellers of good commodities would be economically 'punished' and those of bad commodities rewarded. This negative externality between sellers of indistinguishable commodities of different quality leads to the negative or adverse selection.

Adverse selection can cause the owners of good items to leave the market, so that only bad items remain. By means of that, many gains from trade are lost, because people who would otherwise trade, would not trade. In extreme cases, this phenomenon can completely destroy the market for certain goods. 
The seminal article that introduced the problem of asymmetric information into economic theory is George Akerlof: "The Market for Lemons: Quality Uncertainty and the Market Mechanism", Quarterly Journal of Economics, $84 / 1970,488-500$, in the context of the market for used cars, where some cars are in good state, 'plums', while the others are in bad state, 'lemons'. The current owner of each car knows its quality, but the prospective purchasers don't know whether any given car is a plum or a lemon. For this work, Akerloff was awarded the 2001 Nobel Prize in economics.

One way to solve the problem of asymmetric information is to amend for the uncertainty about the quality of the goods by the actions of the agents in question. For example, the sellers of good cars could afford to offer a warranty, while those of bad cars could not. Therefore, the offer of a warranty would be a credible signal that could separate good from bad cars.

Another notable example of the market where asymmetric information is important, that is of concern to us, is the labor market, because it is not easy to distinguish between productive and less productive workers. This point has repercussions on our understanding of the education market, as education can serve as a signal that can separate workers of different quality, essentially because it is more costly, in terms of effort, (and also money, because of the longer time needed for graduation), for less productive workers to attain education. The basic model and its consequences is introduced in the next section.

\subsection{Illustrative model of signaling in the education and labor markets}

Signaling related to labor and education market was first examined by Michael Spence in his $\mathrm{PhD}$ thesis in 1972 and subsequently succinctly presented in Michael Spence: "Job Market Signaling", Quarterly Journal of Economics $3 / 1973,355-374$. Original model is simple and with very illustrative graphs, but stylized version that appears in Hal R. Varian, Intermediate Microeconomics: A Modern Approach, W.W. Norton \&Company - New York 2010, 727 - 730 is more accessible, so we will follow it here.

There are only two groups of workers, able with marginal product $a_{2}$, and unable with marginal product $a_{1}, a_{2}>a_{1}$. Fraction of able workers is $b$, and consequently, fraction of unable workers is $1-b$. With linear production function the total product is $L_{2} a_{2}+a_{1} L_{1}$, where $\mathrm{L}_{i}$ denotes the number of respective workers.

If the type of workers could be easily observable, each kind of workers would gain the competitive wage equal to her marginal product, $w_{i}=a_{i}$. If on the other hand firms cannot observe productivity of the workers, they would have to pay the wage equal to the average product, $w_{i}=(1-b) a_{1}+b a_{2}$. Still, the overall output would be the same, profits the same, the only difference being the redistribution among two types of workers, in favor of less able. 
If, now, the workers can purchase a signal that can distinguish them, like education, the situation changes. By $e_{i}$, we will denote the quantity of acquired education by each type of worker, and by $c_{i}$ the costs of acquiring the unit of education. Since type two workers are more able, their cost is assumed less, $c_{1}>c_{2}$.

It turns out that equilibrium in this situation is that unable workers acquire 0 level of education, while able workers acquire $e^{\star}$ level of education, where $e^{*}$ satisfies the following inequalities:

$$
\frac{a_{2}-a_{1}}{c_{1}}<\dot{e}<\frac{a_{2}-a_{1}}{c_{2}}
$$

The result is the so called separating equilibrium, because able workers have by way of purchasing education signal separated themselves from unable ones, and are now paid their marginal product. From the social point of view, however, the education signal, since it is presumed to be only a signal that does not raise productivity, is a total waste.

The model therefore shows the situation completely opposite to the human capital theory, namely education in this model does not raise productivity at all; it just serves to signal to the employers something about the workers characteristics, namely their innate productivity (unaltered by acquired education).

Similar case is the famous 'sheepskin effect' in the returns to education'. It has often been observed that there is a large gap in wages between the people who graduate and those who drop out, even if the difference between the two is only in the few remaining exams. Since it does not look likely that just one or two more exams can make such a difference in productivity, the reason for this discontinuous non-linear jump in economic returns begged an explanation. Since the diplomas were traditionally written on sheepskins, this phenomenon became known as sheepskin effect.

One of the explanations in economic literature for this effect, that is relevant for the topic discussed in this section, is presented in Weiss Andrew: "High school graduation, performance, and wages", Journal of Political Economy 4 /1988, 785-820.

Weiss found that graduation is not correlated with output per hour, and that graduates did not appear to have comparative advantage in more complex jobs. This would suggest that wage differentials are not due to higher productivity gained by acquiring additional skills, as would suggest baseline human capital theory, but that there must be another explanation, based on signaling theory. Graduation sends a signal.

9 Hungerford Thomas Solon Gary. (1987): "Sheepskin Effects in the Returns to Education", Review of Economics and Statistics, 69/1987, 175-77. 
Weiss also found that graduates were significantly less likely to quit or to be absent, and since quits and absences are costly to firms, they prefer those less likely to quit or to be absent, and use graduation as a signal to that effect!

Graduates get more because they are indeed more productive, but this productivity is not the result of education and graduation, graduation has just revealed their intrinsic higher productivity, in that they have lower quits and absentee rate.

This explanation that education can serve to emit signals about various intrinsic characteristics of employees, and that its effect is not necessarily limited to the content of the curricula, is the key to our explanation of generally perceived favorable employment opportunities of graduates from private universities in Serbia, which is the subject of the next section.

\subsection{Comparative employment opportunities of graduates from public and private universities}

After the theoretical foundation has been laid in the previous two sections, we can now proceed to the central topic of this chapter, the discussion of comparative employment opportunities of graduates from public $v s$. private universities in Serbia.

The question is very novel and interesting, though, at this moment, the unavailability of data prevents exact scrutiny. Therefore it is only possible to have a hypothetical theoretical analysis, based on the prevailing sentiments as a first guess. It is probable that in the future there will be more statistical data concerning the employment, specific by universities from which employees have graduated. Then it would be easy to group the data according to whether universities are public or private, or according to other classifications of interest.

The starting point of this discussion is relatively widespread impression that graduates from private universities find jobs relatively easy. This is despite the fact that public universities have much longer tradition and are perceived as being more difficult and demanding. The explanation that we offer for this apparent paradox is based on the signaling theory. We have seen that the difference between human capital theory and signaling theory is in that the later deemphasizes the significance of the curricula, and emphasizes intrinsic characteristics of graduates, that are only revealed by means of education. In simple models like the one we introduced in the previous section the extreme assumption that the education doesn't affect worker productivity at all was taken.

In reality, of course, both human capital and signaling play part in the explanation of employment opportunities. And it might well be that for some jobs like the positions of top management of the Central Bank, the graduates from the public universities would have an advantage at present time, but for the majority 
of average jobs that prevail on the market we argue that signaling might be even more important.

It is, of course, also possible that, even from the point of view of human capital theory, the curricula on private universities are better suited to the market demand, and therefore lead to higher productivity, as overinflated curricula of some public universities does not necessarily mean higher productivity.

If we accept the signaling paradigm, that it is not that much that different productivity results from the differences in the study programs themselves, but that degrees on different universities send different signals about the intrinsic characteristics of the candidates, then we are led to inquire what kind of signals are sent by different diplomas. We would summarize the possible difference in signals into following three groups.

Firstly, students who attend private universities tend to be more oriented toward future employment. Having invested in tuition fees, they expect a return. On the other hand, studying for free on the public universities can be a way to meaningfully spend time without too much pressure to look for the job. Employers, I would argue value the commitment of employees to the job.

Secondly, employers know the same what most citizens know, that it was traditionally very hard and tiresome to graduate from the public universities in Serbia. The fact that average time of studies was significantly higher than four years, sometimes even double that time, testifies to that. After graduating, students would probably need considerable time to recover. On the other hand students on private universities, studying in far more student friendly environment tend to better preserve their energy. I would argue that this might also be very important to employers.

And thirdly, it is possible that students on private universities, being enrolled to the universities that are themselves market entities that compete and behave according to the laws of market economy, that they internalize much of that market culture, and that this market behavior might be another trait that is appreciated by the employers.

It remains for future research to follow the dynamic developments in this field, and it is to be expected that there will be more research by means of surveys of employers, and also that Statistical Office and National Employment Office would come out with more statistical data.

\section{Prospects for the development of education in Serbia}

For a relatively small country like Serbia that has passed through a very difficult period of history, integration of its education system into an international arena is essential. The system of high education has been radically transformed to comply with the Bologna Declaration of 19 June 1999. It is to be expected that 
the principles of Bologna: easily readable and comparable degrees, establishment of a system of credits and promotion of mobility will ensure convergence of education systems and quality improvements and assurance.

The convergence to the education systems of developed countries has also resulted in the reform of curricula and especially significant is the fact that many foreign textbooks have been translated, especially in the field of economics. There is also much more versatility in textbooks for primary and secondary schools. Teachers can choose among different publishing houses, and although there might be some incentive problems associated, this is a step in right direction.

These positive processes of convergence are compounded by one of the most important changes in recent time, the emergence of private schools and universities. Since at present, the mechanisms for competition and innovation exist mainly between different schools and universities, while there is not much institutional framework for competition among teachers and managers within the public sector, the private sector has great potential to contribute to the development of education and innovation in Serbia.

However, the fact that private sector has to compete with public sector which is subsidized and mostly provided for free certainly limits its scope. Therefore, it should be considered how state could help the development of private sector. At present, even the scientific databases that are provided for free to the public sector are not shared with the private sector, although it would certainly be more economic for the country if the terms would be negotiated for all the universities united.

Although this is not always very popular among the general public, economists have always been arguing for market approach, based on free enterprise and competition, where it is also important to have an equal playground. These principles of innovation, free enterprise and competition, as well as remuneration according to the results, should be enhanced also within the public sector. Otherwise, a lot of the potential for innovation that could come from within the pool of educators and that could be screened out through the education system to eventually provide best practices and clue in what direction system should evolve, would be lost.

At any rate, significant breakthroughs in education are possible only when education is recognized as the key factor in the development of the society.

\section{Conclusion}

In this article we have explored how two main strands of the economic theory of education could be related to the education in Serbia. The rough estimate of the rate of return to education was obtained at around $10 \%$. This moderately high rate of return shows that: 1 . Education is a good investment for an individual in Serbia; 2. It explains high demand for education from both public and pri- 
vate universities; 3 . Moderately high rate of return makes it economically viable to finance education from loans. 4. Estimation of the ROR of education makes possible comparisons with other countries in this respect. Further research could refine these initial estimates.

The question of comparative employment opportunities as between graduates from public and private universities was examined as a novel topic resulting from the changes in education system in Serbia after privatization and market economy was introduced. Since there are still no available data, at this point only theoretical analysis and informed hypothesis could be set for future research to confirm or alter.

Generally perceived good employment opportunities of graduates from private universities, despite the favorite position of public education, could be explained in part by more market oriented curricula. This part of explanation would belong to the realm of classical human capital theory.

The second part of explanation could be found in the realm of signaling theory, as general wisdom suggests that significant part of the curricula is not what the employers are relying on when making employment decisions. Signals that education sends might also be of great importance, and some of the signals that graduates from private universities might send are identified to be: 1 . Studies oriented toward the employment, 2. Preserved energy due to the student-friendly environment, 3. Entrepreneurial or market oriented spirit.

It remains for further empirical research to develop on these ideas. The contribution of this article has however been to draw the attention to the importance of signaling in this context.

\section{Literature}

- Akerlof George (1970): “The Market for Lemons: Quality Uncertainty and the Market Mechanism", Quarterly Journal of Economics, 84/1970, 488-500

- Blaug Mark (1978): Economics of Education: A Selected Annotated Bibliography, Pergamon Press Oxford

- Hanushek A. Eric Welch Finis (eds.) (2006): Handbook of the Economics of Education, North Holland Amsterdam.

- Hungerford Thomas Solon Gary. (1987): "Sheepskin Effects in the Returns to Education", Review of Economics and Statistics 69/1987, 175-77.

- Johnes, Geraint Johnes Jill (eds.) (2004): International handbook on the economics of education, Edward Elgar Cheltenham, UK

- Smith, Adam ([1776] 1991), The Wealth of Nations, Alfred A. Knopf New York 
- Spence Michael (1973): “Job Market Signaling”, Quarterly Journal of Economics, 3/1973, 355-374

- Statistical Office of the Republic of Serbia (2013): "Employees in legal entities in the Republic of Serbia, by salaries and wages size and level of educational attainment, March 2013 (ZP12)", http://webrzs.stat.gov.rs/ WebSite/repository/documents/00/01/07/99/zp12072013e.pdf (06.09.2013).

- Varian R. Hal (2010): Intermediate Microeconomics: A Modern Approach, W.W. Norton \&Company New York.

- Weiss Andrew (1988): "High school graduation, performance, and wages”, Journal of Political Economy, 4/1988, 785-820. 